\title{
The Effect Of Mining Activities On The Quality Conditions Of Fe In Wastewater At Tenggarong East Kalimantan
}

\author{
Sujiman $^{1}$ \\ ${ }^{1}$ Teacher Staff Faculty of Engineering Kutai Kartanegara Tenggarong University East Kalimantan. Indonesia
}

\begin{abstract}
This study aims: to determine the quality of waste $\mathrm{Fe}$ in the mining and settling pond inlet, determine the trend of $\mathrm{Fe}$ waste at the mine site, and to determine the trend of $\mathrm{Fe}$ waste in processing sites in 2018. The research was carried out by coming directly to the field and then taking samples of wastewater with a ballast bottle. Data analysis method by comparing with environmental quality standards. The results showed that the quality of Fe wastewater at mine sites 1 from January to September 2018 ranged from 0.27 $\mathrm{mg} / \mathrm{lt}$ to $6.45 \mathrm{mg} / \mathrm{lt}$ still below the environmental quality standard. Mine Location 2 showed that Fe content is between $1,72 \mathrm{mg} / \mathrm{lt}$ to $62.30 \mathrm{mg} / \mathrm{lt}$, which is above the environmental quality standard in February of $34.14 \mathrm{mg} / \mathrm{lt}$ and March $62.30 \mathrm{mg} / \mathrm{lt}$. Whereas in mine 3 showed is the Fe content is between $0.15 \mathrm{mg} / \mathrm{lt}$ to $27 \mathrm{mg} / \mathrm{lt}$, the level of which is above the quality standard in January February and May 2018. Whereas at the processing location 1 results from an analysis of Fe content between $0.009 \mathrm{mg} / \mathrm{lt}$ to $3,21 \mathrm{mg} / \mathrm{lt}$ is still below the environmental quality standard. Whereas in processing area 2 between $0.07 \mathrm{mg} / \mathrm{lt}$ to $3.16 \mathrm{mg} / \mathrm{lt}$ is still below the environmental quality standard. Evaluation of the trend in the level of Fe that is striking at mining locations 1 and 2 in March 2018. Whereas at mining site 3 in February 2018.
\end{abstract}

Keywords: wastewater; Fe content; mine Location; processing location.

\section{Introduction}

The process of open coal mining will produce waste. Water flowing at the mine site is indicated to contain heavy metals that can contaminate aquatic bodies. Such as mining activities at Pangkalan Kuansing, that the heavy metal content of $\mathrm{Fe}$ in the inlet and outlet settling pond, population wells are $8.85 \mathrm{mg} / \mathrm{lt}, 8.26 \mathrm{mg} / \mathrm{lt} ; 7.07 \mathrm{mg} / \mathrm{lt}$; $6.76 \mathrm{mg} / \mathrm{lt}[1]$.

The same research conducted by Hidayanti et al [2] showed that the initial characteristics of young and old mine water in the Bangka Belitung Islands were due to mining activities so that the water was contaminated with heavy metals Fe and Mn.

Mining activities carried out in the Santan River area will also produce Fe waste around the waters around the mine, so the Santan River is included in classes I and II of quality standards, which can be used as drinking water or for other consumption purposes and can be used for water recreation, cultivation or infrastructure. freshwater fish, livestock and irrigating plants [3].

As a result of the mining process around Tenggarong, it also results in $\mathrm{Fe}$ waste, so research needs to be carried out entitled The Effect of Mining Activities on Fe Quality
Conditions on Wastewater in Tenggarong East Kalimantan.

\section{Methodology}

The location of research are is in Pondok Labu Subdistrict, Tenggarong District, Kutai Kartanegara Regency, East Kalimantan. Water samples are taken with ballast bottles with a 2 liter per bottle size, at the location of the settling pond inlet in the 5 locations in five locations namely 3 locations in the mine and 2 locations in the processing of coal. water sampling is taken on top, middle and bottom of the settling pond. The data collection from January to September 2018. Data analysis method by comparing with environmental quality standards from Regional Regulation of the Governor of East Kalimantan, Number 2 of 2011.

\section{Results and Discussion}

\subsection{Quality Fe at Mining and Processing}

Sampling The quality of wastewater in 2018 carried out by the Mining Region 1 from January to September 2018,

\footnotetext{
*Corresponding author: kasnadisujiman@gmail.com
} 
where the main parameter monitored for wastewater is Total Iron. The quality of wastewater for Fe parameters in March is quite high but still below the environmental quality standard. Whereas in other months the quality is quite low.

The quality of wastewater in 2018 at the mine Location 2 from January to September 2018. The quality of wastewater for Fe parameters in February and March is high and above the environmental quality standard. While in other months the quality is low to rather high.

The results of the measurement of 2018 wastewater quality at the mining location 3 from January to September 2018, the quality of wastewater for $\mathrm{Fe}$ parameters in January February and May is high and above the environmental quality standard. While in other months the quality is low.

The results of the measurement of 2018 wastewater quality in the processing area 1 from January to September 2018, the quality of wastewater for $\mathrm{Fe}$ parameters, in general, is of low quality.

The results of the measurement of 2018 wastewater quality in by Processing area 2 from January to September 2018, the quality of wastewater for Fe parameters, in general, is of low quality only in May is quite high. Quality of Wastewater Fe Parameters at Mine Location and Processing in 2018 can be seen in Table 1.

Table 1. Quality of Wastewater Fe Parameters at Mine Location and Processing in 2018

\begin{tabular}{|l|c|c|c|c|c|c|}
\hline \multirow{2}{*}{ No. } & Measurement of & \multicolumn{5}{|c|}{ Quality of Fe (mg/lt) } \\
\cline { 3 - 7 } & $\begin{array}{c}\text { Moon } \\
\text { The year 2018 }\end{array}$ & $\begin{array}{c}\text { Location } \\
\text { Mining 1 }\end{array}$ & $\begin{array}{c}\text { Location } \\
\text { Mining 2 }\end{array}$ & $\begin{array}{c}\text { Location } \\
\text { Mining 3 }\end{array}$ & $\begin{array}{c}\text { Location } \\
\text { Processing 1 }\end{array}$ & $\begin{array}{c}\text { Location } \\
\text { Processing 2 }\end{array}$ \\
\hline 1 & January & 0.27 & 7.00 & 11.53 & 0.35 & 0.44 \\
\hline 2 & February & 2.44 & 34.14 & 27.00 & 1.66 & 2.57 \\
\hline 3 & March & 6.45 & 62.30 & 1.28 & 2.77 & 1.87 \\
\hline 4 & April & 2.37 & 5.56 & 4.48 & 2.71 & 2.36 \\
\hline 5 & May & 0.90 & 5.37 & 9.46 & 1.01 & 7.11 \\
\hline 6 & June & 2.54 & 1.72 & 1.67 & 1.20 & 3.16 \\
\hline 7 & July & 1.05 & 3.34 & 2.63 & 3.21 & 1.39 \\
\hline 8 & August & 1.64 & 2.18 & 0.15 & 0.09 & 0.07 \\
\hline 9 & September & 2.34 & 1.26 & 1.70 & 1.72 & 1.02 \\
\hline
\end{tabular}

Source: Results of Laboratory Analysis of the Industrial Research and Development Agency Samarinda Research Center and Standardization in 2018.

\subsection{Evaluation of Trends in the Quality of Fe Wastewater at Mine Locations}

Evaluation of Waste Water Trends at the mine site in the 2018 period, from January the level of Fe quality increased to March with a level of 6.45 and then the level decreased until September 2018, but still below the standard quality level. This is influenced by January in March March at the mine site is digging an overburden layer in the form of siltstone containing $\mathrm{Fe}$, so that it affects the quality of wastewater. Trend Evaluation Charts from the Inlet Settling Pond Waste Water analysis results before processing compared to the applicable Quality Standards can be seen in Figure 1 below.

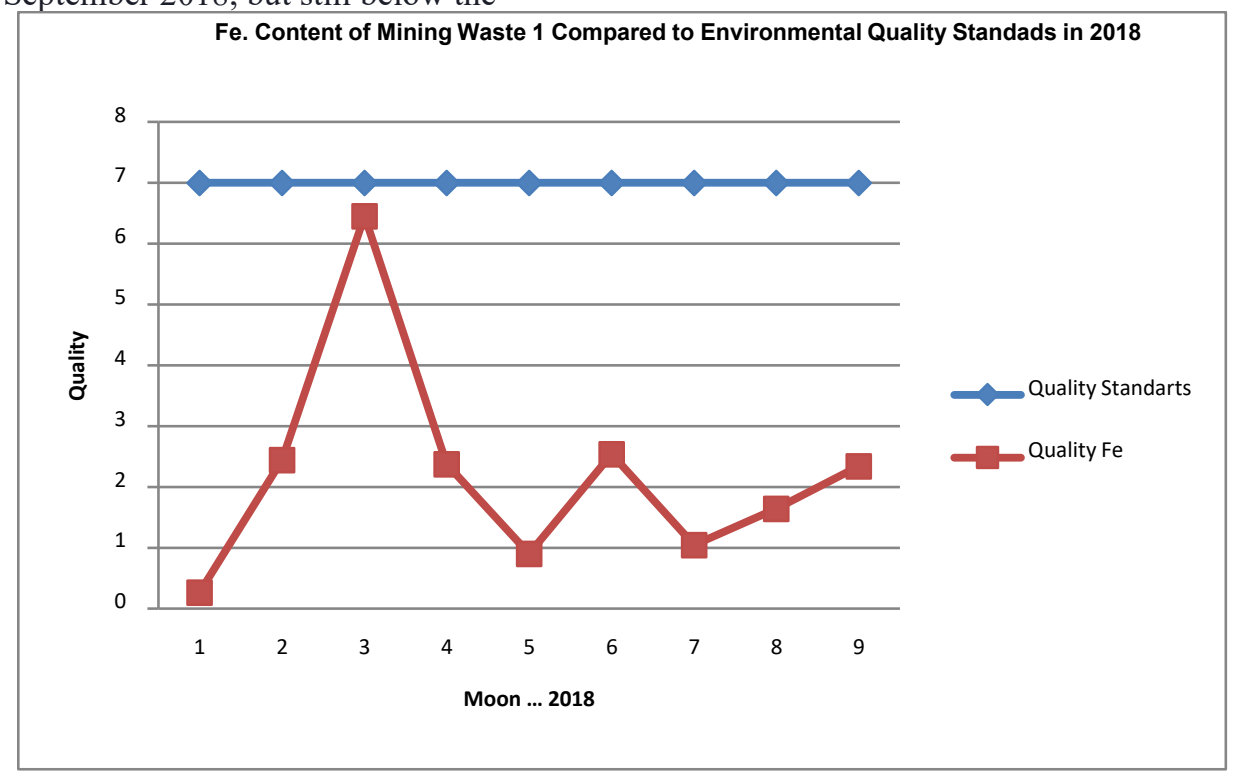

Fig. 1. Graph of Fe Quality Trends in Mine Locations 1 
Evaluation of Waste Water Trends at the mine site 2 for the 2018 period is different from mine 1, that from January the levels go up to March with levels of 62.3 $\mathrm{mg} / \mathrm{lt}$, then these levels decrease until September 2018. This is influenced by when during January to March at the mine site is digging an overburden layer in the form of sandstone containing nodules of the more dominant Fe element, thus affecting the quality of wastewater. Trend Evaluation Charts from the Inlet Settling Pond Waste Water analysis results before processing compared with applicable Quality Standards can be seen in Figure 2 below.

\section{Fe Content of Mining 2 Compared to Environmental Quality Standards in 2018}

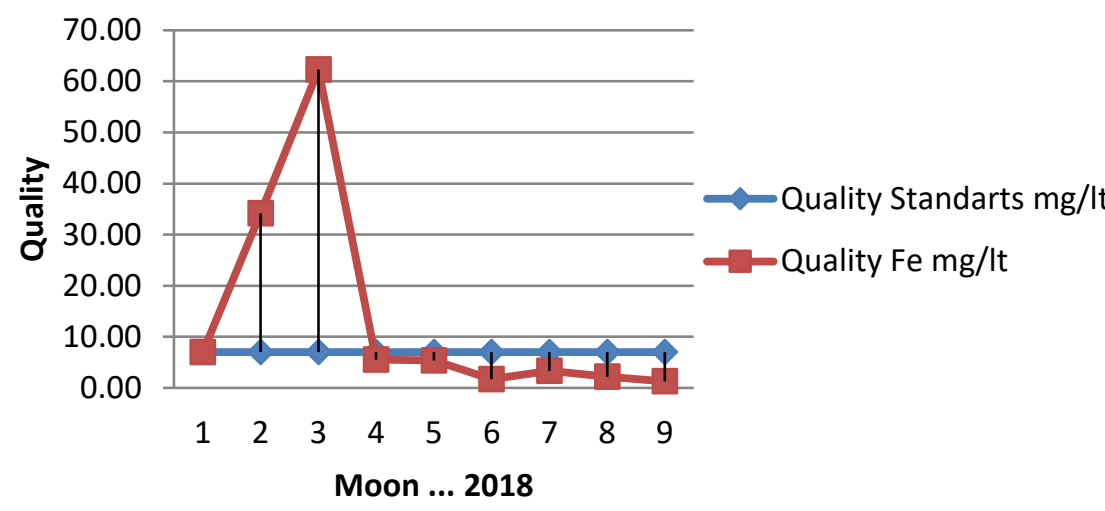

Fig. 2. Graph of Fe Quality Trends in Mine Location 2

Evaluation of Waste Water Trends at the mine site 3 for the period 2018 is almost the same as mine 2, that from January the levels rose up to February with levels of 27 $\mathrm{mg} / \mathrm{lt}$, then these levels decreased until September 2018. This was influenced by during January to February at the mine site is digging an overburden layer in the form of sandstone containing nodules of the element Fe, thus affecting the quality of wastewater. The trend evaluation graph from the results of the Inlet Settling Pond Wastewater Analysis before processing compared to the applicable Quality Standards can be seen in Figure 3 below

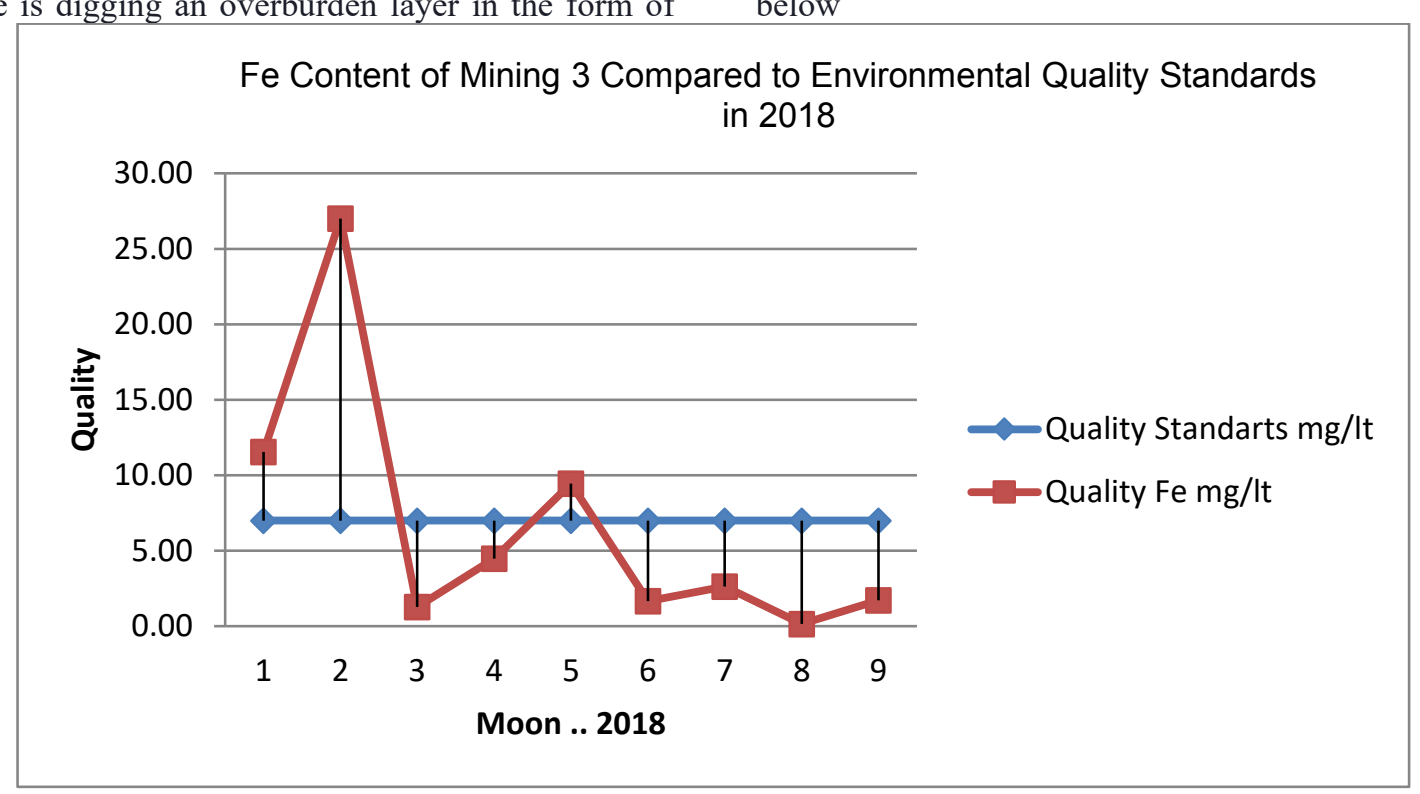

Fig. 3. Graph of Fe Quality Trends in Mine Location 3 


\subsection{Evaluation of Trends in the Quality of Wastewater in the Coal Processing Locations.}

Tendency Evaluation Graph from the results of Inlet Settling Pond Wastewater Analysis at the Coal Processing site 1 shows that the increase and decrease in Fe content are normal because at this location bioremediation management has been carried out so that the wastewater is normal. Graph of Fe Fe Trends in Processing Location 1 can be seen in Figure 4 below

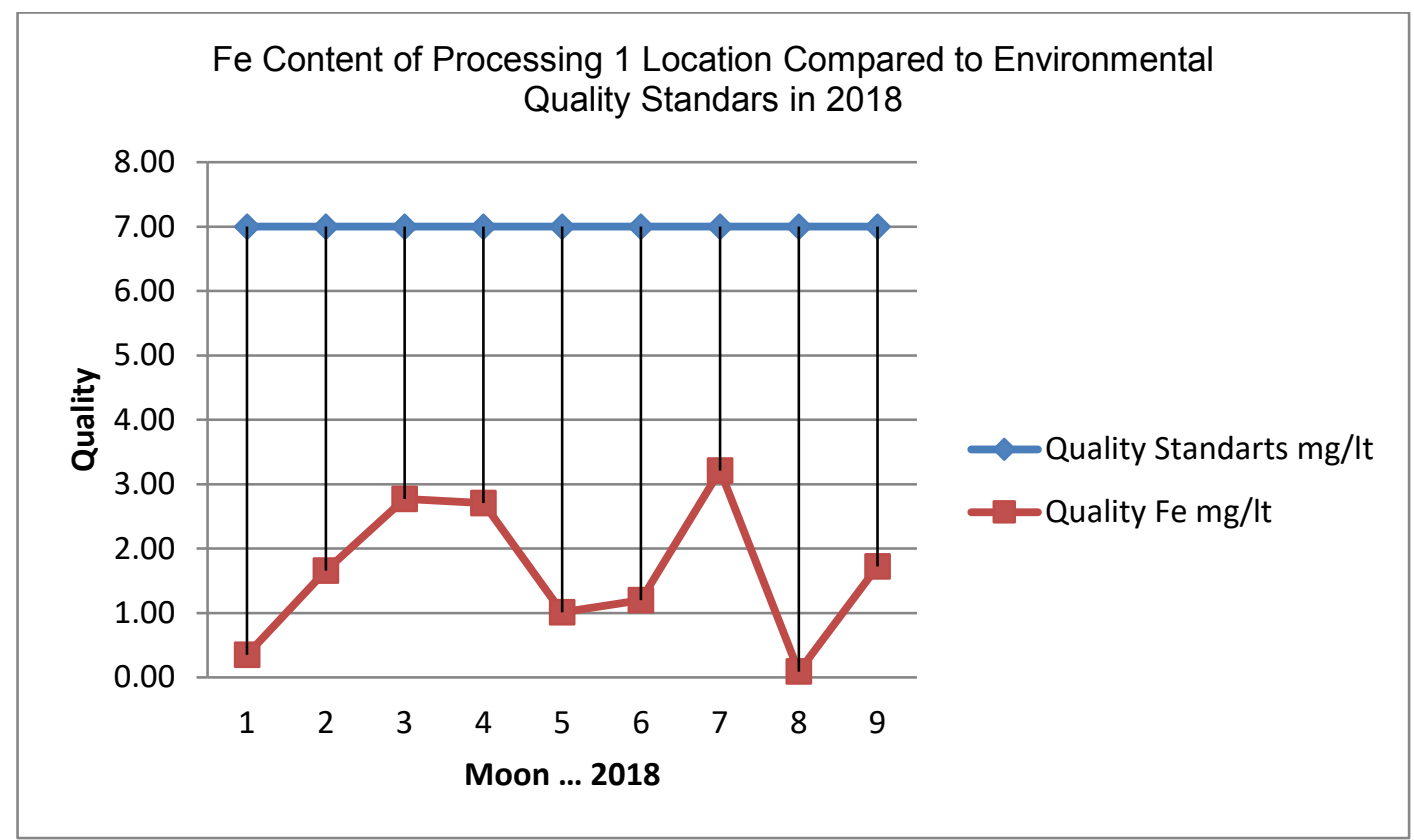

Fig. 4. Graph of Fe Quality Trends in Processing Sites 1

The Tendency Evaluation Graph from the results of Inlet Settling Pond Wastewater Analysis at the Coal Processing site 2 shows that the increase and decrease in Fe content tends to increase to seven in May 2018 then decrease again, but this level is still below the quality standard, because at this location has been done management of bioremediation so that wastewater is normal. Graph of Fe Trends in Processing Location 1 can be seen in Figure 5 below.

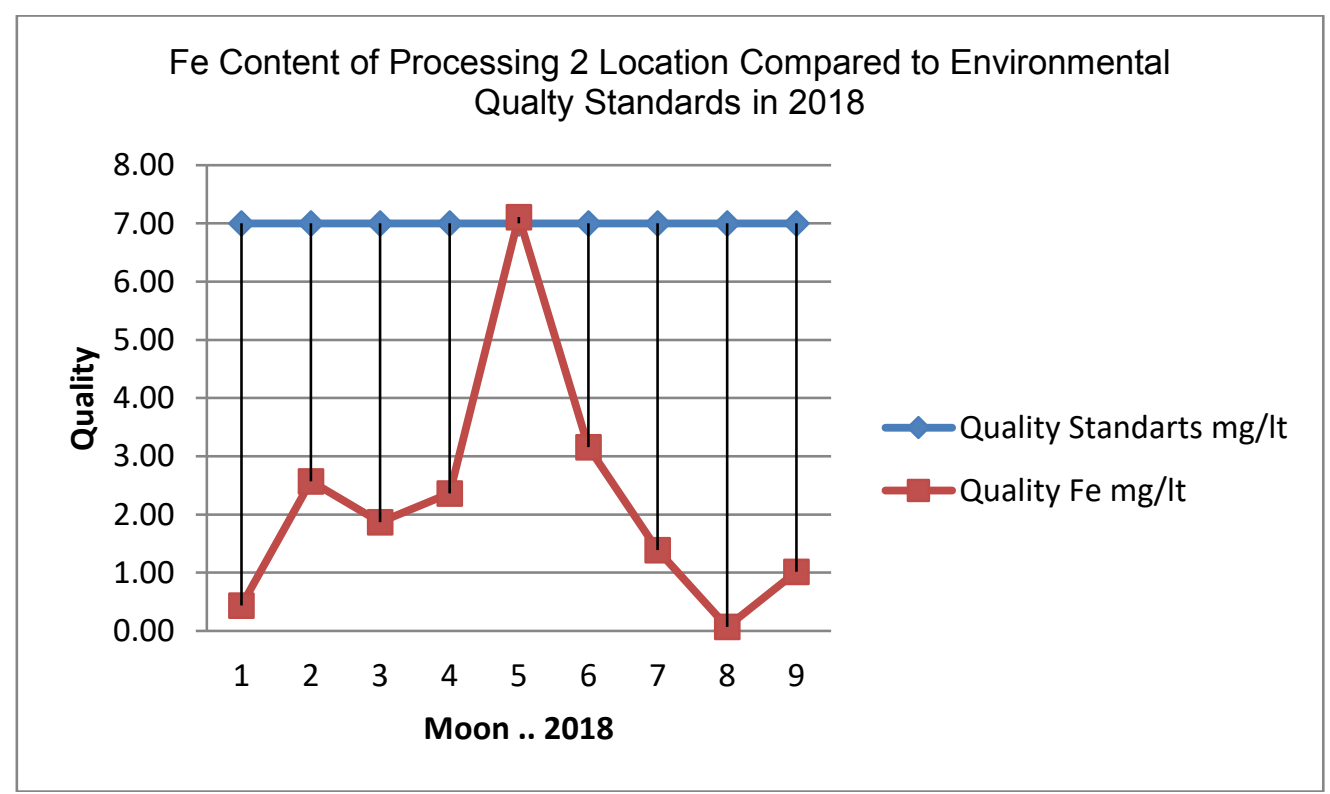

Fig. 5. Graph of Fe Quality Trends in Let Settling Pond Processing Location 2 


\section{Conclusion}

The results of laboratory analysis of Fe content of wastewater at mine site 1 from January to September 2018 showed that Fe content was still below environmental quality standards.

Mine Location $2 \mathrm{Fe}$ content is above the environmental quality standard in February of $34.14 \mathrm{mg} / \mathrm{lt}$ and March $62.30 \mathrm{mg} / \mathrm{lt}$. Mine 3, the $\mathrm{Fe}$ content is above the environmental quality standard in January February and May 2018. Whereas in the processing location 1 results from the analysis of $\mathrm{Fe}$ content are still below the environmental quality standard. Processing area 2 there is still below the environmental quality standard. Evaluation of the trend in the level of Fe that is striking at mining location 1 and location of storage 2 in March 2018.

The author gratefully acknowledges thanks to Mr. Kirtiadi and management from PT Tanito Harum Coal Mining for giving me funding, place, and opportunity for this research.

\section{Reference}

1. Kurniawan F., Hanifah. T. A., Subardi., Analisis Logam (Fe, Pb), Nitrat (No3 -), Dan Sulfida (S2-) Pada Limbah Tambang Batubara Pt. Tri Bakti Sarimas Di Desa Pangkalan Kuansing. Bidang Kimia Analitik Jurusan Kimia Fakultas Matematika dan Ilmu Pengetahuan Alam Kampus Binawidya Pekanbaru, 28293, Indonesia (2015)

2. Hidayanti. N., Rezagama. A, Luvita. V., Pengolahan Logam Fe Dan Mn Dalam Air Dengan Metode Ozonasi (O3) Dan Adsorpsi (Studi Kasus : Danau Bekas Tambang Di Kepulauan Bangka Belitung. Program Studi Teknik Lingkungan Fakultas Teknik Universitas Diponegoro J1. Prof. H. Sudarto, SH Tembalang, Semarang, Indonesia 50275 (2015)

3. Fathirizki. K. A., at all,. Kandungan Logam Berat Besi (Fe), Timbal (Pb) dan Mangan (Mn) Pada Air Sungai Santan Heavy Metal Content Iron (Fe), Lead $\mathrm{Pb}$ ) and Manganese (Mn) in The Water of The Santan River., Universitas Mulawarman, Samarinda Jalan Kuaro, Gn. Kelua, Samarinda Ulu, Kota Samarinda, Kalimantan Timur 75119 (2018) 